\title{
Fecal production by sea urchins in native and invaded algal beds
}

\author{
Leah K. Sauchyn*, Robert E. Scheibling \\ Biology Department, Dalhousie University, Halifax, Nova Scotia B3H 4J1, Canada
}

\begin{abstract}
To examine the role of fecal production by the sea urchin Strongylocentrotus droebachiensis in native and invaded algal assemblages in Nova Scotia, Canada, we examined the quantity (production rate by urchin feeding aggregations, or 'fronts') and quality (organic carbon and nitrogen content) of feces egested on 3 diets: (1) a native kelp Saccharina longicruris, (2) kelp encrusted with the invasive bryozoan Membranipora membranacea, and (3) an invasive green alga Codium fragile ssp. fragile. Relatively low absorption of clean and encrusted kelp resulted in high fecal output from urchins grazing native and invaded kelp beds (74 and $81 \mathrm{~g}_{\text {feces }} \mathrm{m}^{-1}$ front $\mathrm{d}^{-1}$, respectively). In contrast, high absorption of $C$. fragile resulted in low fecal output from urchins grazing meadows of the

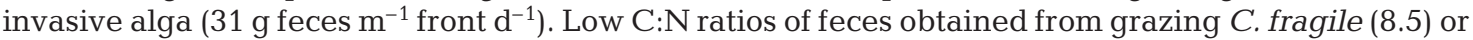
encrusted kelp (11.4), compared to clean kelp (30.7), suggest that feces from invaded assemblages are a higher quality food source for microbes and detritivores. To compare dispersal characteristics of feces from each diet, we measured pellet shape, size, density, and settling and critical erosion velocities. Using a wave model, we estimated the depth at which feces would be deposited under seasonally varying wave conditions. We found that pellets of $C$. fragile are likely deposited at the greatest depths (33 to $55 \mathrm{~m}$ ), pellets of clean kelp at intermediate depths (28 to $47 \mathrm{~m})$, and pellets of encrusted kelp at the shallowest depths (22 to $40 \mathrm{~m}$ ). Our findings suggest a smaller amount of higher quality feces enters the detrital food web at greater depths from Codium meadows than from native kelp beds.
\end{abstract}

KEY WORDS: Feces · Invasive species ' Codium fragile Kelp bed ' Membranipora membranacea Rocky subtidal zone 'Saccharina longicruris ' Strongylocentrotus droebachiensis

Resale or republication not permitted without written consent of the publisher

\section{INTRODUCTION}

Historically, the shallow rocky subtidal zone on the Atlantic coast of Nova Scotia, Canada, has alternated between 2 community states: highly productive algal beds dominated by the kelps Saccharina longicruris and Laminaria digitata and less productive urchin barrens dominated by crustose coralline algae. The cycling between these states is driven by fluctuations in the abundance of sea urchins Strongylocentrotus droebachiensis (Miller 1985, Scheibling 1986). At high population densities (up to 500 urchins $\mathrm{m}^{-2}$ ), urchins form grazing aggregations (fronts) along the lower margin of kelp beds, driving the transition to barrens (Breen \& Mann 1976, Scheibling et al. 1999, LauzonGuay \& Scheibling 2007a). During these destructive grazing events, urchins consume a large amount of kelp biomass: up to $1 \mathrm{~kg} \mathrm{~m}^{-1}$ front $\mathrm{d}^{-1}$ along fronts that extend from $100 \mathrm{~s}$ of $\mathrm{m}$ to kilometers alongshore (Scheibling et al. 1999, Miller \& Nolan 2000, LauzonGuay \& Scheibling 2007a). The material not absorbed is egested from the urchins as globular, mucus-covered fecal pellets (Lawrence \& Klinger 2001). Suspended urchin feces pervade the water column around fronts and deposit in depressions on the seabed (Fig. 1a). Although the pivotal role of grazing by $S$. droebachiensis in regulating the structure and dynamics of benthic communities is well established (reviewed by Scheibling \& Hatcher 2007), the importance of fecal production by urchins, as an energy source for detrital food webs, has received little attention (Mamelona \& Pelletier 2005, Sauchyn \& Scheibling 2009).

The encrusting bryozoan Membranipora membranacea, which is native to the North Pacific 

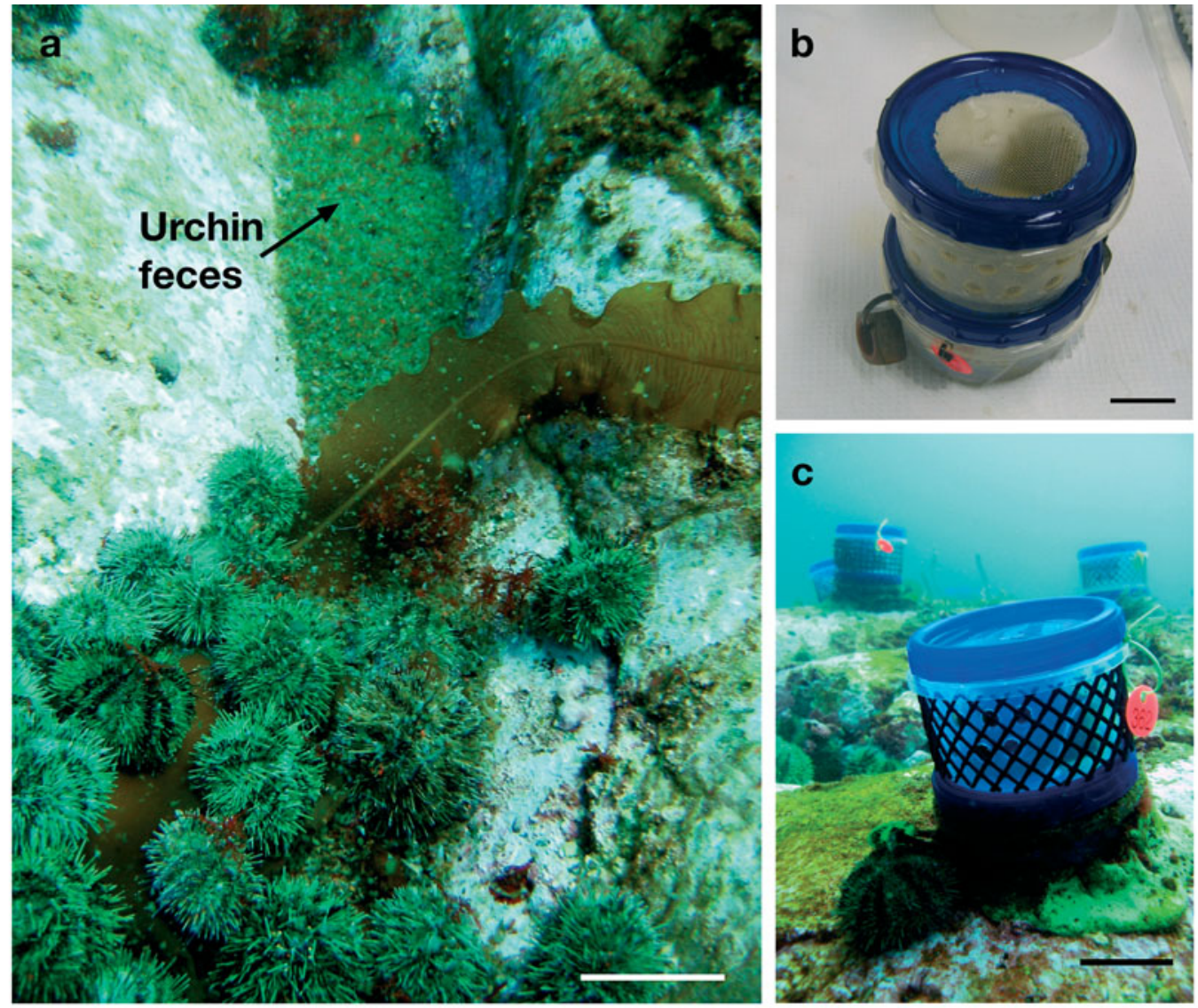

Fig. 1. (a) Strongylocentrotus droebachiensis feeding on kelp at Splitnose Point, with feces deposited in background; (b) 2-tiered feeding container used in laboratory feeding experiments; (c) in situ containers used in field experiments. Scale bars are $5 \mathrm{~cm}$

(Schwaninger 2008), was first reported growing on kelps in Nova Scotia in 1992 (Scheibling et al. 1999), following its introduction into the Gulf of Maine in 1987 (Berman et al. 1992). Recurrent outbreaks of M. membranacea, which alters the structural integrity of kelp fronds, have resulted in large-scale defoliation of kelp beds throughout this region (Lambert et al. 1992, Scheibling et al. 1999, Scheibling \& Gagnon 2009). The loss of kelp canopy has facilitated the establishment and spread of another invasive species, the green alga Codium fragile fragile (previously $C$. fragile tomentosoides, Provan et al. 2008; hereafter C. fragile) (Levin et al. 2002, Chapman et al. 2002). Once established, C. fragile inhibits the recruitment and recolonization of kelp and other native seaweeds (Levin et al. 2002, Scheibling \& Gagnon 2006), leading to gradual replacement of kelp beds by meadows of the invasive alga (Harris \& Tyrrell 2001, Chapman et al. 2002). Currently, C. fragile forms dense meadows in the shallow rocky subtidal zone (Scheibling \& Gagnon 2006, Schmidt \& Scheibling 2006, Theriault et al. 2006) and in intertidal pools (Bégin \& Scheibling 2003, Schmidt \& Scheibling 2005), along the Atlantic coast of Nova Scotia.
Laboratory and field experiments have shown that laminarian kelps (Saccharina longicruris and Laminaria digitata) are the preferred food of Strongylocentrotus droebachiensis (Scheibling \& Hatcher 2007). In nature, however, sea urchin consumption is dependent upon both food preference and availability (Lawrence 1975). Urchins readily graze Codium fragile when other fleshy macroalgae are not available (Scheibling \& Anthony 2001, Sumi \& Scheibling 2005). When both $C$. fragile and kelps are present, urchin fronts consume kelp first, although remaining thalli of $C$. fragile are eventually grazed by trailing urchins (Lyons \& Scheibling 2008). Loss of kelp fronds associated with outbreaks of Membranipora membranacea may accelerate destructive grazing by reducing the available kelp biomass (Scheibling et al. 1999, Lauzon-Guay \& Scheibling 2007a).

The role of fecal production by Strongylocentrotus droebachiensis in the shallow rocky subtidal zone is determined by the production rate, quality, and dispersal of the fecal pellets. The quantity and quality of fecal material produced on a particular algal diet depends on the consumption rate and absorption efficiency of 
urchins, and on the chemical composition of the food. Decreased survival, growth, and reproduction of $S$. droebachiensis feeding on Codium fragile (Scheibling \& Anthony 2001, Lyons \& Scheibling 2007a), compared to urchins fed kelp, suggest that $C$. fragile is a poor food source due to its chemical composition and/or low absorption by urchins. In contrast, Membranipora membranacea may increase the nutritional value of kelp by increasing the protein content, which could alter urchin consumption rate and/or absorption efficiency (Nestler \& Harris 1994, Knip \& Scheibling 2007). Diet can also affect the settling and critical shear velocities of fecal pellets by influencing their shape, size, and density (Taghon et al. 1984, Turner 2002). For example, the presence of inorganic material, such as $\mathrm{CaCO}_{3}$ in $M$. membranacea, may decrease horizontal advection and increase deposition (Miller et al. 2002, Giles \& Pilditch 2004).

To assess the impact of invasions by Membranipora membranacea and Codium fragile on the production and export of fecal particulate matter derived from grazing of algal beds in the shallow subtidal zone, we compared the quantity, quality (organic carbon and nitrogen content) and physical characteristics (shape, size, density, settling and critical erosion velocities) of fecal pellets egested by urchins fed kelp Saccharina longicruris, kelp encrusted with $M$. membranacea, and C. fragile. We used these measures to estimate rates of fecal production by urchin populations feeding on kelp beds with and without the invasive bryozoan, or on meadows of $C$. fragile. Differences in the estimated urchin fecal output among these algal assemblages, and in the nutritional value and dispersal potential of the feces produced in each case, indicate that invasive species may have a significant effect on nutrient cycling and energy flow that extends far beyond the invaded range and into adjacent deeper water communities.

\section{MATERIALS AND METHODS}

Field feeding experiment. To compare in situ consumption rates of individual sea urchins Strongylocentrotus droebachiensis on (1) kelp (Saccharina longicruris), (2) kelp encrusted with Membranipora membranacea, and (3) Codium fragile, we conducted a $24 \mathrm{~h}$ feeding experiment on 20 September 2008 at Splitnose Point $\left(44^{\circ} 22.61^{\prime} \mathrm{N}, 63^{\circ} 32.74^{\prime} \mathrm{W}\right)$ at the mouth of Ketch Harbour, Nova Scotia, Canada. At this time, a luxuriant kelp bed extended from the low intertidal to a depth of 6 to $8 \mathrm{~m}$ (chart datum) and over an offshore distance of $\sim 150 \mathrm{~m}$. A dense urchin front was grazing the kelp bed along its lower margin, creating urchin barrens dominated by crustose coralline algae. For a de- tailed description of the site and urchin-kelp bed dynamics see Lauzon-Guay \& Scheibling $(2007 a, b)$.

Sea urchins were collected by SCUBA divers from the barrens on 17 September. Large adult urchins ( 45 to $60 \mathrm{~mm}$ test diameter, $\mathrm{n}=24$ ) were haphazardly selected and placed individually in $500 \mathrm{ml}$, screw-top Ziploc ${ }^{\circledR}$ containers perforated with 22 holes $(1 \mathrm{~cm})$ and covered with $1 \mathrm{~cm}$ Vexar $^{\circledR}$ mesh (Fig. 1c). The 24 containers containing urchins and 9 containers to be used for autogenic controls were attached to bases anchored to the substrate (Z-Spar A-788 Splash Zone Compound) in the urchin barrens at $6 \mathrm{~m}$ below chart datum. The urchins were left undisturbed for $3 \mathrm{~d}$ prior to commencing the feeding experiment. Temperature was recorded at $6 \mathrm{~m}$ every $30 \mathrm{~min}$ (StowAway TidbiT Temp Logger). Mean ( $\pm \mathrm{SD}$ ) temperature over the course of the experiment was $13.11 \pm 0.67^{\circ} \mathrm{C}$.

On 20 September 2008, divers placed a known quantity of food from each diet in 8 containers with urchins and 3 without (autogenic controls). The clean and encrusted kelp was collected at Splitnose Point on 17 September, and Codium fragile was collected at Cranberry Cove ( $30 \mathrm{~km}$ to the east) on 18 September 2008. Kelp was considered encrusted if at least $50 \%$ of the blade was covered with Membranipora membranacea. The food was supplied in excess of what urchins are known to consume (as wet weight) in $24 \mathrm{~h}$ : clean kelp 8.9 to $13.8 \mathrm{~g}$ (Scheibling \& Hatcher 2007); encrusted kelp 9.4 to $16.7 \mathrm{~g}$ (Knip \& Scheibling 2007); C. fragile 16.8 to $24.5 \mathrm{~g}$ (Sumi \& Scheibling 2005). After $24 \mathrm{~h}$, the containers were collected, the urchins removed, and the remaining algae returned to the laboratory and weighed. The regression of urchin wet weight $(W, g)$ to test diameter $\left(D, \mathrm{~mm}_{i} W=0.005 D^{2.44}, \mathrm{r}^{2}=0.990, \mathrm{n}=72\right)$ obtained from urchins collected at Splitnose Point on 17 September for the laboratory feeding experiment was used to convert field consumption rates to $g$ wet weight consumed $\mathrm{g}^{-1}$ urchin $\mathrm{d}^{-1}$. Individual consumption rates were adjusted according to changes in weight of autogenic controls (clean or encrusted kelp: no change; $C$. fragile: gain of $0.4 \mathrm{~g}[ \pm 0.16 \mathrm{SE}]$ )

Laboratory feeding experiment. To compare the absorption efficiency of total material, organic carbon, and nitrogen of urchins feeding on the same 3 diets as in the field experiment, we conducted two $24 \mathrm{~h}$ feeding experiments on 28 September and 3 October 2008. We also collected feces to compare the quality (organic carbon and nitrogen content) and physical characteristics (shape, size, density, settling and critical erosion velocities) of each fecal pellet type. The urchins and food used in the laboratory feeding experiment were collected at the same time and place as those used in the field feeding experiment. Urchins $(n=72)$ with test diameters 45 to $60 \mathrm{~mm}$ were randomly assigned to each of the 3 diets $\left(24\right.$ urchins diet $^{-1}$ ). All urchins were 
fed their respective diets ad libitum starting on 22 September 2008 in $47 \mathrm{l}$ flow-through seawater aquaria. To determine individual consumption and defecation rates and to collect intact feces, a 2-tiered feeding container was created (Fig. 1b). The top $500 \mathrm{ml}$, screw-top Ziploc $^{\circledR}$ container, which contained the urchin, was perforated with 22 holes $(1 \mathrm{~cm})$ and covered with 1000 $\mu \mathrm{m}$ Nitex ${ }^{\circledR}$ mesh to prevent loss of feces. The lid of the bottom container was attached to the base of the top container with nylon screws and bolts. The center of the lid was cut out and covered with $1 \mathrm{~cm}$ Vexar ${ }^{\circledR}$ mesh to allow feces to settle into the bottom container. For each feeding experiment, 45 feeding containers, 36 containing urchins and 9 without (autogenic controls), were randomly assigned to 2 stacked, 2651 flowthough seawater tables with 12 air stones per table to increase oxygenation and circulation (water temperature: 10.2 to $10.4^{\circ} \mathrm{C}$ ). The average transit time for material in the gut of Strongylocentrotus droebachiensis is 2 d (Lawrence \& Klinger 2001). Therefore, to ensure that the feces egested came from the laboratory diet, the 36 urchins in each feeding trial were individually fed their respective diets ad libitum for $3 \mathrm{~d}$ prior to each experiment.

On 28 September and 3 October, all remaining algae and feces were removed from the feeding containers and a known quantity of food from each of the 3 diets was added to 12 containers with urchins and 3 containers without urchins (autogenic controls). Again, the amount of food provided was in excess of what urchins are known to consume in $24 \mathrm{~h}$ : clean kelp 7.2 to $16.3 \mathrm{~g}$; encrusted kelp 7.5 to $18.8 \mathrm{~g}$; Codium fragile 21.3 to $37.6 \mathrm{~g}$. After $24 \mathrm{~h}$, urchins and the remaining algae were removed and weighed. Laboratory consumption rates ( $g$ wet weight $\mathrm{g}^{-1}$ urchin $\mathrm{d}^{-1}$ ) were adjusted for changes in weight of autogenic controls (clean or encrusted kelp: no change; $C$. fragile: loss of $0.1 \mathrm{~g}[ \pm$ $0.05 \mathrm{SE}])$. Samples of each algal type were weighed and dried for $72 \mathrm{~h}$ at $60^{\circ} \mathrm{C}$ to determine wet to dry weight conversions: clean kelp $0.159 \pm 0.011 \mathrm{~g}$ (mean \pm $\mathrm{SE}, \mathrm{n}=12)$; encrusted kelp $0.163 \pm 0.008 \mathrm{~g}(\mathrm{n}=12) ; C$. fragile $0.052 \pm 0.001 \mathrm{~g}(\mathrm{n}=7)$. These ratios were used to convert both field and laboratory consumption rates to $g$ dry weight consumed $\mathrm{g}^{-1}$ urchin $\mathrm{d}^{-1}$. Feces from 6 containers from each diet and feeding trial were used to determine defecation rates. The feces were filtered onto pre-combusted GF/F filters $(0.7 \mu \mathrm{m})$, transferred to pre-weighed, acid washed, $20 \mathrm{ml}$ scintillation vials, and dried at $60^{\circ} \mathrm{C}$ for $48 \mathrm{~h}$. Defecation rate was expressed as $\mathrm{g}$ dry weight defecated $\mathrm{g}^{-1}$ urchin $^{-1}$.

Organic carbon and nitrogen content. Dried algal samples $(n=12)$ and dried fecal samples $(n=12)$ from each diet in the laboratory experiment were used to determine organic carbon and nitrogen content of the algae and feces, respectively. Algal samples were ground in a coffee grinder, and fecal samples were ground with a mortar and pestle. Encrusted kelp and feces from this diet were acidified prior to analysis to remove $\mathrm{CaCO}_{3}$ from Membranipora membranacea. Small aliquots of $1 \mathrm{~N} \mathrm{HCl}$ were added to each sample drop by drop, drying in between at $40^{\circ} \mathrm{C}$, until no more $\mathrm{CO}_{2}$ was released (Kennedy et al. 2005, Komada et al. 2008). The procedure was repeated twice more to ensure that all $\mathrm{CaCO}_{3}$ was removed. Samples were dried overnight at $60^{\circ} \mathrm{C}$ and re-ground with mortar and pestle prior to analysis. All samples were analyzed for organic carbon and nitrogen content by flash combustion at $1000^{\circ} \mathrm{C}$ using a Perkin Elmer $3400 \mathrm{CHN}$ analyzer.

Absorption efficiency. The absorption efficiency of food material consumed for each diet in the laboratory experiment was calculated as the difference between consumption and defecation rates, and expressed as a percentage of consumption rate:

$$
\begin{gathered}
\text { Absorption efficiency }=(\text { consumption rate }- \\
\text { defecation rate }) / \text { consumption rate } \times 100
\end{gathered}
$$

To determine the rate of carbon and nitrogen ingestion and egestion for each diet (mg dry weight $\mathrm{g}^{-1}$ urchin $\mathrm{d}^{-1}$ ), the carbon and nitrogen content of algal and fecal samples were multiplied by the average laboratory consumption and defecation rates on the respective diet. These estimates were used to calculate organic carbon and nitrogen absorption efficiencies:

$\mathrm{C}$ absorption efficiency $=(\mathrm{C}$ ingestion rate -
$\mathrm{C}$ egestion rate $) / \mathrm{C}$ ingestion rate $\times 100$

$\mathrm{N}$ absorption efficiency $=(\mathrm{N}$ ingestion rate $\mathrm{N}$ egestion rate)/ $\mathrm{N}$ ingestion rate $\times 100$

Measures of absorption efficiency in the laboratory were then used to estimate field defecation rates ( $g$ dry weight feces $\mathrm{g}^{-1}$ urchin $\mathrm{d}^{-1}$ ) based on field consumption rates. The organic carbon and nitrogen contents of algal samples were also multiplied by the average field consumption rates to determine the rate of carbon and nitrogen ingestion for each diet in the field (mg dry weight $\mathrm{g}^{-1}$ urchin $\mathrm{d}^{-1}$ ). These estimates, in conjunction with carbon and nitrogen absorption efficiencies, were used to estimate the rate of in situ fecal organic carbon and nitrogen production.

Shape, size, settling velocity, and density. Feces from 3 containers from each diet and feeding trial in the laboratory experiment were used to measure pellet shape, size, and settling velocity and to calculate pellet density. A new, uncut lid was placed on the bottom container immediately after removing it from the seawater table to ensure that the feces remained intact in seawater. To determine pellet shape and size, an image of the undisturbed feces at the bottom of the 
container was taken with a Canon Powershot A95 ${ }^{\circledR}$ Digital Camera (5.0 megapixels). The length of the major $(a, \mathrm{~mm})$ and minor $(b, \mathrm{~mm})$ axes of the 5 fecal pellets, in each sample, closest to the calibration ruler $( \pm 0.001 \mathrm{~mm})$ placed on the bottom of the container, was estimated using ImageJ (v. 1.39). Fecal pellet shape was calculated as the ratio of minor to major axes $(b / a)$. Size was calculated as equivalent circular diameter $(D=\sqrt{ } a b, \mathrm{~mm})$.

Settling velocity $\left(w_{s}\right)$ was estimated by gently releasing the feces used in size and shape estimates, just below the water surface in a $20 \times 20 \times 80 \mathrm{~cm}$ settling chamber. The surrounding air and water temperature within the settling chamber were held constant at $17.0^{\circ} \mathrm{C}$. Particles were recorded settling between 35 and $40 \mathrm{~cm}$ below the water surface on digital video (SONY DCR-VX2000 MiniDV Handycam ${ }^{\circledR}$ ), and the video was analyzed using iMovie (v. 3.0.3, 2003). Settling velocity was calculated as the distance travelled, determined by a scale attached to the outer wall of the settling chamber, over time elapsed on the video $(\mathrm{cm}$ $\mathrm{s}^{-1}$ ). Settling velocity was estimated for 5 pellets from each sample.

Pellet density $\left(\mathrm{kg} \mathrm{m}^{-3}\right)$ was estimated for each diet from density versus settling velocity curves. Settling velocity depends on pellet density, size $(D, \mathrm{~mm})$, shape (Corey Shape Factor), and smoothness (surface texture), and seawater density and viscosity (Dietrich 1982). The curves were generated using pellet sizes estimated for each diet, a Powers Index of 3.5 (a measure of smoothness typical of natural particles, Dietrich 1982), and a Corey Shape Factor (CSF, assuming intermediate and minor axes are equal) for each diet calculated as:

$$
\mathrm{CSF}=b /(\sqrt{ } a b)
$$

We calculated seawater density and viscosity from the temperature $\left(17.0^{\circ} \mathrm{C}\right)$ and salinity (32) of the seawater in the settling chamber.

Critical shear velocity. Feces from 3 containers from each diet and feeding trial were used to measure pellet critical shear velocity $\left(u_{* \text { crit, }} \mathrm{cm} \mathrm{s}^{-1}\right)$. Again, the feces were contained in seawater in the bottom container to minimize disturbance. To estimate critical shear velocity, the feces were gently released from the bottom container onto the working section $(39 \times 48 \mathrm{~cm})$ of a $7 \mathrm{~m}$ recirculating flume (water temperature $=17.2^{\circ} \mathrm{C}$ ). The working section was made of granite tile to simulate the natural substratum. The free-stream velocity $\left(u, \mathrm{~cm} \mathrm{~s}^{-1}\right)$ in the flume was increased slowly from 0 to $20 \mathrm{~cm} \mathrm{~s}^{-1}$ in $15 \mathrm{~s}$ time intervals over $5 \mathrm{~min}$, by increasing the frequency of the Powerflex $40^{\circledR}$ flume motor. The movement of pellets on the working section of the flume was recorded by a video camera (SONY DCRVX2000 MiniDV Handycam ${ }^{\circledR}$ ) mounted above the flume. The number of pellets that began eroding at each free-stream velocity was determined using iMovie (v. 3.0.3, 2003).

To relate free-stream velocity to shear velocity $(u *$, $\left.\mathrm{cm} \mathrm{s}^{-1}\right), \log$-velocity profiles were generated at $u=5$, 10,15 , and $20 \mathrm{~cm} \mathrm{~s}^{-1}$. Water velocity $\left(u[z], \mathrm{cm} \mathrm{s}^{-1}\right)$ was measured at heights $(z, \mathrm{~cm})$ of 0.1 to $23.6 \mathrm{~cm}$ (height of free-stream velocity) above the working section of the flume using a Nortex AS Vectrino ${ }^{\circledR}$ velocimeter. The shear velocity was estimated from the mean slope of duplicate log-velocity profiles obtained at each of the 4 free-stream velocities:

$$
\ln \left(z / z_{0}\right)=\left(u / u_{*}\right) u(z)
$$

where $z_{0}$ is the roughness length $(\mathrm{cm})$, calculated by iteration assuming hydraulically smooth flow: $z_{0}=$ $v / 9 u_{*}$ and $u_{*}=\kappa u(z) / \ln \left(z / z_{0}\right)$; kinematic viscosity $\left(v, m^{2}\right.$ $\mathrm{s}^{-1}$ ) is $1.14 \times 10^{-6} \mathrm{~m}^{2} \mathrm{~s}^{-1}$ at $17.2^{\circ} \mathrm{C}$ and a salinity of 32 (Soulsby 1997), and von Karman's constant ( $\kappa)$ is 0.4 . The linear regression between $u_{*}$ and $u$ was used to convert free-stream velocities at which initial motion was observed, to critical shear velocities $\left(u_{*}=0.0769 u\right.$, $\left.r^{2}=0.988\right)$.

Statistical analysis. To test for an effect of diet on individual field and laboratory consumption rates and laboratory defecation rates ( $g$ dry weight $\mathrm{g}^{-1}$ urchin $\mathrm{d}^{-1}$ ), we used 1-way analysis of variance (ANOVA) followed by Tukey's HSD tests. There was no effect of feeding trial (28 September, 3 October) or seawater table level (upper or lower tier) on laboratory consumption and defecation rates. These factors were removed from the models. The laboratory consumption and defecation rates were log transformed to meet the assumptions of homogeneity of variance (Levene's test, $\alpha=0.05$ ) and normality (Shapiro-Wilk, $\alpha=0.05$ ).

Multivariate analysis of variance (MANOVA) was used to compare the organic carbon and nitrogen content among the 3 algal diets and fecal pellet types. A significant multivariate result was followed by 1-way ANOVA and Tukey's HSD tests. Fecal carbon and nitrogen contents were log transformed to meet the assumption of homogeneity of variance-covariance matrices (Levene's and Box's $M$-tests, $\alpha=0.05$ ).

MANOVA was also used to test for an effect of diet on fecal pellet shape, size $(\mathrm{mm})$, settling velocity $\left(\mathrm{cm} \mathrm{s}^{-1}\right)$, and density $\left(\mathrm{kg} \mathrm{m}^{-3}\right)$. Pellet density was log transformed to meet the assumption of homogeneity of variance (Levene's test, $\alpha=0.05$ ). A significant multivariate result was followed by 1-way ANOVA and Tukey's HSD tests. We also tested for the effect of diet on critical shear velocity $\left(\mathrm{cm} \mathrm{s}^{-1}\right)$ of fecal pellets using 1-way ANOVA and Tukey's HSD tests. The data met the assumptions of normality (Shapiro-Wilk test, $\alpha=0.05$ ) and homogeneity of variance (Levene's test, $\alpha=0.05$ ). 


\section{RESULTS}

Consumption and defecation rates. Individual consumption rates were 1.5 times higher in the field than in the laboratory; in the field, they did not differ among diets of Codium fragile, clean kelp, or kelp encrusted with Membranipora membranacea $\left(F_{2,20}=\right.$ 1.802, $\mathrm{p}=0.191$ ) (Fig. 2a). In contrast, there was a significant effect of diet on both consumption $\left(F_{2,32}=\right.$ 4.816, $\mathrm{p}=0.015)$ and defecation rates $\left(F_{2,33}=52.9\right.$, $\mathrm{p}<0.001$ ) in the laboratory (Fig. 2a,b). Individual urchins consumed significantly less $C$. fragile than encrusted kelp ( $p=0.012)$. In addition, urchins produced significantly less fecal material when feeding on $C$. fragile than on clean $(\mathrm{p}<0.001)$ or encrusted ( $\mathrm{p}$ $<0.001$ ) kelp (Fig. 2b). Defecation rates did not differ significantly between diets of clean or encrusted kelp $(p=0.669)$. As a result of the low defecation rate, absorption efficiency of total material was higher when urchins were feeding on $C$. fragile than on clean or encrusted kelp (Table 1). Field defecation rates, calculated from absorption efficiencies measured in the laboratory, showed the same pattern as laboratory defecation rates, i.e. much lower fecal pro-
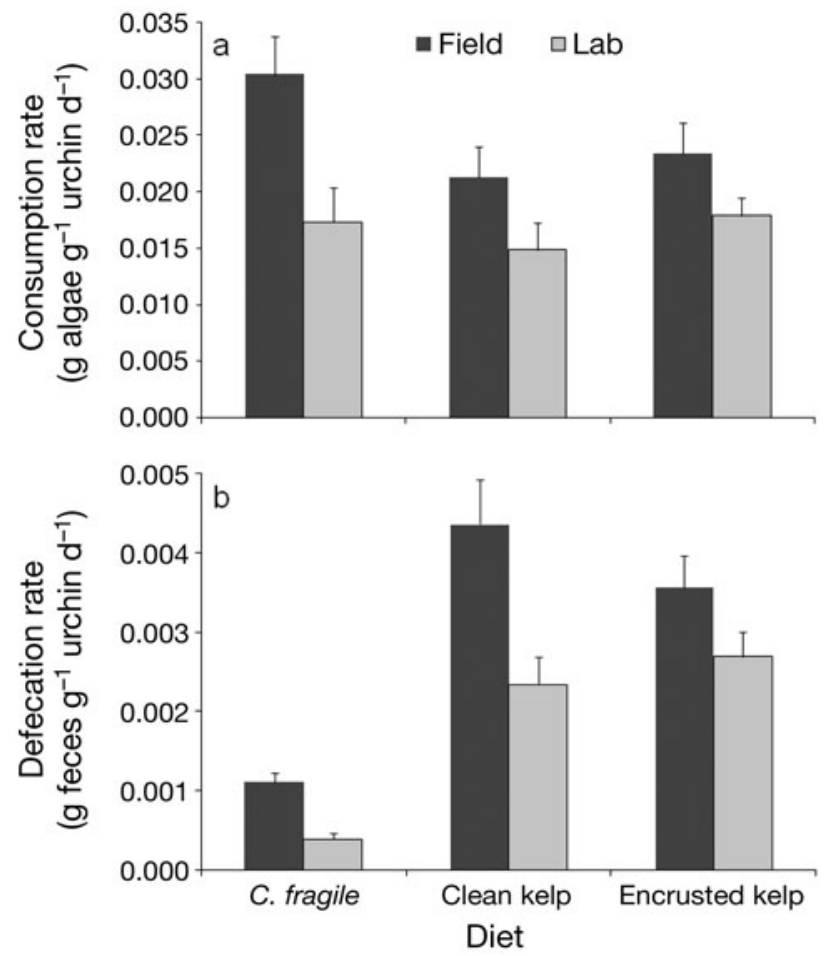

Fig. 2. Strongylocentrotus droebachiensis. Field and laboratory (a) consumption and (b) defecation rates ( $g$ dry weight $\mathrm{g}^{-1}$ urchin $\mathrm{d}^{-1}$ ) of urchins feeding on Codium fragile, clean Saccharina longicruris, and $S$. longicruris encrusted with Membranipora membranacea. Data are mean +1 SE $(n=8$ field, $\mathrm{n}=12$ laboratory) duction when urchins fed on $C$. fragile than on kelp (Fig. 2b).

Organic carbon and nitrogen content. Organic carbon and nitrogen content varied among algal diets $(\lambda=$ $\left.0.042, F_{4,64}=62.5, \mathrm{p}<0.001\right)$ and fecal pellet types $(\lambda=$ $\left.0.086, F_{4,64}=38.5, \mathrm{p}<0.001\right)$. Organic carbon content was higher in clean kelp than in encrusted kelp $(\mathrm{p}<$ $0.001)$ and Codium fragile $(\mathrm{p}<0.001)$, and higher in encrusted kelp than in C. fragile ( $\mathrm{p}<0.001$; Fig. 3a). In contrast, nitrogen content was similar in $C$. fragile and encrusted kelp, and lowest in clean kelp $(p<0.001$ for both pairwise comparisons; Fig. 3a). The difference in organic carbon and nitrogen content among algal diets

Table 1. Strongylocentrotus droebachiensis. Absorption efficiency $(\%)$ of urchins feeding on Codium fragile, clean Saccharina longicruris, and S. longicruris encrusted with Membranipora membranacea. Data are mean \pm 1 SE $(n=12)$

\begin{tabular}{|lccc|}
\hline Diet & Dry weight & Organic carbon & Nitrogen \\
\hline C. fragile & $86.7 \pm 3.8$ & $89.1 \pm 0.9$ & $87.3 \pm 0.8$ \\
Clean kelp & $64.8 \pm 3.0$ & $77.1 \pm 0.8$ & $77.8 \pm 1.9$ \\
Encrusted kelp & $68.1 \pm 2.6$ & $80.7 \pm 0.5$ & $70.3 \pm 1.9$ \\
\hline
\end{tabular}
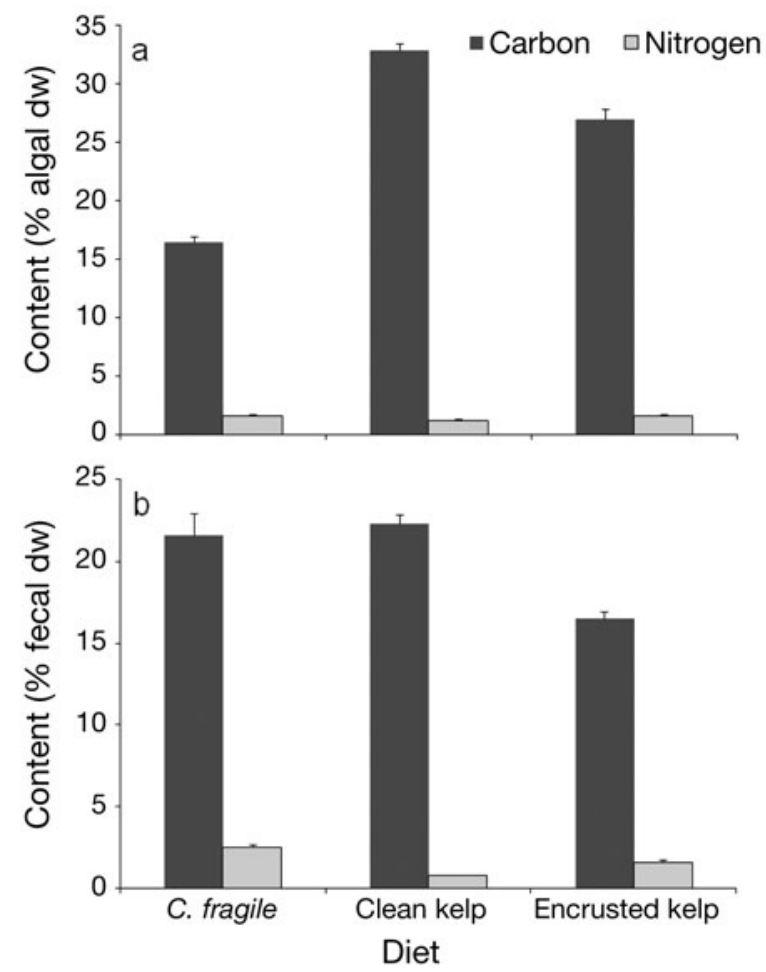

Fig. 3. Strongylocentrotus droebachiensis. Percent composition of organic carbon and nitrogen in (a) Codium fragile, Saccharina longicruris, and S. longicruris encrusted with Membranipora membranacea, and (b) the feces produced by urchins feeding on these 3 diets. Data are mean +1 SE $(\mathrm{n}=12)$. dw: dry weight 
resulted in a high $\mathrm{C}: \mathrm{N}$ ratio in clean kelp, an intermediate ratio in encrusted kelp, and a relatively low ratio in C. fragile (Table 2).

Fecal pellets of urchins fed clean kelp $(p<0.001)$ and Codium fragile $(\mathrm{p}<0.001)$ had a significantly higher content of organic carbon than pellets of urchins fed encrusted kelp (Fig. 3b). Nitrogen content differed among all fecal pellets types $(\mathrm{p}<0.001$ for all pairwise comparisons) and was highest in fecal pellets of $C$. fragile and lowest in pellets of clean kelp (Fig. 3b). Differences in fecal nitrogen content resulted in a relatively low C:N ratio of pellets of $C$. fragile and a high $\mathrm{C}: \mathrm{N}$ ratio of clean kelp pellets. This pattern was also observed in algal C:N ratios. However, the $\mathrm{C}: \mathrm{N}$ ratios of fecal pellets of urchins fed $C$. fragile and of urchins fed encrusted kelp were lower than those of the respective algal diets, while the C:N ratio of pellets of urchins fed clean kelp was higher than that in the alga (Table 2).

The organic carbon and nitrogen absorption efficiencies, in part, reflect these changes in C:N ratios from food to feces. Both carbon and nitrogen absorption efficiencies were highest for Codium fragile (Table 1). Carbon absorption was slightly greater than nitrogen, leading to a lower fecal C:N ratio. Carbon and nitrogen absorption efficiencies were lower for urchins fed encrusted kelp than $C$. fragile, but higher carbon than nitrogen absorption of encrusted kelp led to a decrease in the C:N ratio from food to feces. Carbon and nitrogen absorption efficiencies were similar for clean kelp, but increased variation in nitrogen absorption led to a slight increase in the $\mathrm{C}: \mathrm{N}$ ratio from kelp to feces.

Shape, size, settling velocity, and density. Although the physical characteristics of the fecal pellets varied among diets $\left(\lambda=0.103, F_{8,20}=5.30, \mathrm{p}=0.001\right)$, diet did not significantly affect either pellet shape $\left(F_{2,13}=0.001\right.$, $\mathrm{p}=0.999)$ or size $\left(F_{2,13}=0.627, \mathrm{p}=0.627\right)$ although pellets from both kelp diets were more angular than pellets of Codium fragile (Fig. 4). Shape was highly variable but averaged 0.76 for all fecal pellet types, with 1 being a sphere and values $<1$ becoming more ellipsoidal. Mean \pm SE diameter of fecal pellets was $2.675 \pm$

Table 2. Strongylocentrotus droebachiensis. C:N ratio of Codium fragile, clean Saccharina longicruris, and S. longicruris encrusted with Membranipora membranacea and the feces produced by urchins feeding on these 3 diets. Data are mean $\pm 1 \mathrm{SE}(\mathrm{n}=12)$

\begin{tabular}{|lcc|}
\hline Diet & \multicolumn{2}{c|}{ C:N } \\
& Algae & Feces \\
\hline C. fragile & $10.0 \pm 0.3$ & $8.5 \pm 0.3$ \\
Clean kelp & $28.4 \pm 1.4$ & $30.7 \pm 2.2$ \\
Encrusted kelp & $16.5 \pm 0.7$ & $11.4 \pm 1.1$ \\
\hline
\end{tabular}


Fig. 4. Strongylocentrotus droebachiensis. Fecal pellets produced by urchins feeding on (a) Codium fragile, (b) clean Saccharina longicruris, and (c) S. longicruris encrusted with Membranipora membranacea. Scale bar is $1 \mathrm{~mm}$

$0.267 \mathrm{~mm}$ for urchins fed Codium fragile, $2.365 \pm 0.267$ $\mathrm{mm}$ for urchins fed clean kelp, and $2.391 \pm 0.277 \mathrm{~mm}$ for urchins fed encrusted kelp. Despite similarities in shape and size, settling velocity $\left(F_{2,13}=22.0, \mathrm{p}<0.001\right)$ and density $\left(F_{2,13}=26.0, \mathrm{p}<0.001\right)$ varied, in a consistent pattern, among fecal pellet types (Fig. 5a,b). Pellets of encrusted kelp had the highest density and settled fastest, although not significantly faster than pellets of clean kelp $(\mathrm{p}=0.115)$. Fecal pellets of $C$. fragile had the lowest density and settled slowest.

Critical shear velocity. Critical shear velocities of fecal pellets varied among diets $\left(F_{2,15}=11.8, \mathrm{p}=0.001\right)$, in a similar pattern to settling velocity and density (Fig. 5c). Fecal pellets of Codium fragile began moving at shear velocities of $0.510 \mathrm{~cm} \mathrm{~s}^{-1}( \pm 0.060 \mathrm{SE})$, while encrusted kelp pellets required significantly higher $(p=0.001)$ shear velocities of $0.894 \mathrm{~cm} \mathrm{~s}^{-1}( \pm 0.036)$ to move. Fecal pellets of clean kelp began moving at intermediate shear velocities of $0.689 \mathrm{~cm} \mathrm{~s}^{-1}( \pm 0.068)$ 


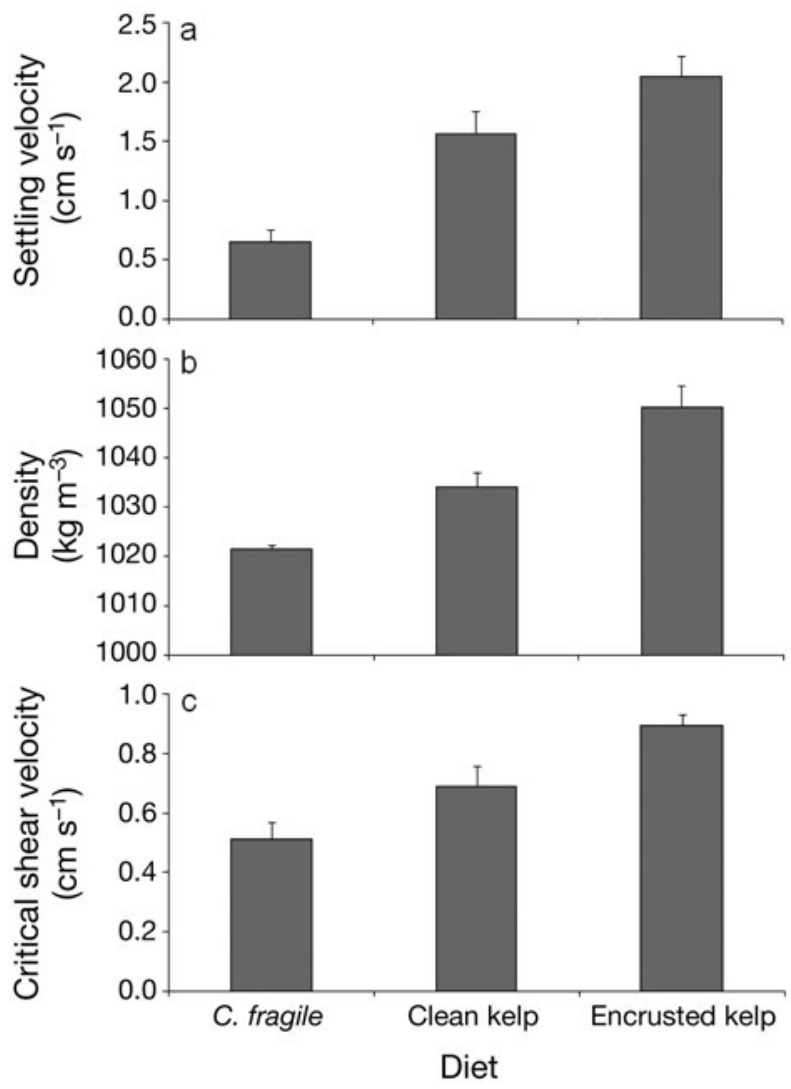

Fig. 5. Strongylocentrotus droebachiensis. (a) Settling velocity, (b) density, and (c) critical shear velocity of fecal pellets produced by urchins feeding on Codium fragile, clean Saccharina longicruris, and $S$. longicruris encrusted with Membranipora membranacea. Data are mean $+1 \mathrm{SE}(\mathrm{n}=6)$

but their average critical shear velocity was not significantly higher than that of pellets of $C$. fragile $(\mathrm{p}=$ 0.094) and marginally lower than encrusted kelp pellets $(p=0.051)$.

\section{DISCUSSION}

\section{Consumption rate}

Although laminarian kelps are a preferred food of Strongylocentrotus droebachiensis (Scheibling \& Hatcher 2007), urchins consume similar amounts of Saccharina longicruris or Codium fragile when fed monospecific diets (Prince \& LeBlanc 1992, Scheibling \& Anthony 2001, Sumi \& Scheibling 2005, Lyons \& Scheibling 2007a,b, this study). Consumption rates of clean kelp in our field experiment $\left(0.009 \mathrm{~g}\right.$ alga $\mathrm{g}^{-1}$ urchin $\mathrm{d}^{-1}$ ) are much lower than previous estimates from Splitnose Point (0.027 $\mathrm{g}$ alga $\mathrm{g}^{-1}$ urchin $\mathrm{d}^{-1}$; Lauzon-Guay \& Scheibling 2007a) and Little Duck Island (45 km to the east; $0.04 \mathrm{~g}$ algae $\mathrm{g}^{-1}$ urchin $\mathrm{d}^{-1}$;
Scheibling et al. 1999). The previous estimates were calculated from the rate of front advance and the biomass of kelp at the edge of the bed, with kelp loss attributed solely to consumption by urchins. Because some loss may occur due to other factors (e.g. fragmentation and drift, grazing by other invertebrates), previous studies may have overestimated urchin consumption rates. Also, our estimate may be low because it was obtained in September when feeding rate is at a seasonal low (Scheibling et al. 1999). Consumption rates of clean kelp in our laboratory experiment $(0.007$ $g$ alga $\mathrm{g}^{-1}$ urchin $\mathrm{d}^{-1}$ ) are within the range of previous

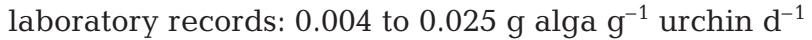
(Larson et al. 1980, Minor \& Scheibling 1997, Lyons \& Scheibling 2007b). In contrast, our laboratory con-

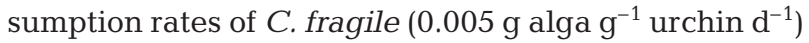
are slightly higher than previous records: 0.002 to $0.004 \mathrm{~g}$ alga g ${ }^{-1}$ urchin $\mathrm{d}^{-1}$ (Prince \& LeBlanc 1992, Scheibling \& Anthony 2001, Sumi \& Scheibling 2005, Lyons \& Scheibling 2007b). Previous feeding experiments were conducted with $\geq 10$ urchins in 47 l aquaria (Scheibling \& Anthony 2001, Sumi \& Scheibling 2005, Lyons \& Scheibling 2007b) or with individual urchins in 31 containers (Prince \& LeBlanc 1992). We fed individual urchins in $500 \mathrm{ml}$ containers where they were in close contact with their food, thus eliminating search time from measures of consumption rate. S. droebachiensis cannot chemically detect $C$. fragile but is strongly attracted to kelp (Prince \& LeBlanc 1992), suggesting that the reduction of search time in small containers likely has a greater effect on estimates of consumption rate for urchins feeding on C. fragile than on kelp. There are no previous estimates of consumption rate of $C$. fragile in the field with which to compare our estimate $\left(0.008 \mathrm{~g}\right.$ alga $\mathrm{g}^{-1}$ urchin $\left.\mathrm{d}^{-1}\right)$.

There was no difference between urchin consumption rates of clean kelp and kelp encrusted with Membranipora membranacea in both our field and laboratory experiments. In contrast, Knip \& Scheibling (2007) found that consumption rate of Strongylocentrotus droebachiensis was significantly lower on bryozoanencrusted kelp (Laminaria digitata) than clean kelp in the laboratory. However, their measure of mean consumption rate on encrusted kelp (0.005 $\mathrm{g}$ alga $\mathrm{g}^{-1}$ urchin $\left.\mathrm{d}^{-1}\right)$ was $44 \%$ lower than ours $(0.009 \pm 0.001 \mathrm{~g}$ alga $\mathrm{g}^{-1}$ urchin $\mathrm{d}^{-1}$ ). Again, there are no previous estimates of consumption rate of encrusted kelp in the field with which to compare our estimate $(0.011 \mathrm{~g}$ alga $\mathrm{g}^{-1}$ urchin $\mathrm{d}^{-1}$ ). Overall, consumption rates measured in our field experiment were higher than those in our laboratory experiment. This may be due to increased water flow and oxygenation in field containers covered with $1 \mathrm{~cm}$ Vexar ${ }^{\circledR}$ mesh, compared to laboratory containers covered with $1000 \mu \mathrm{m}$ Nitex ${ }^{\circledR}$ mesh (to retain feces). 


\section{Defecation rate and absorption efficiency}

Unlike consumption rate, defecation rate depended on diet and was significantly lower for urchins feeding on Codium fragile than on clean or encrusted kelp. Our estimate of defecation rate for Strongylocentrotus droebachiensis fed clean kelp $\left(0.002 \mathrm{~g}_{\text {feces }} \mathrm{g}^{-1}\right.$ urchin $\left.\mathrm{d}^{-1}\right)$ is similar to that measured by Mamelona \& Pelletier (2005) in the laboratory $\left(0.003 \mathrm{~g}_{\text {feces }} \mathrm{g}^{-1}\right.$ urchin $\mathrm{d}^{-1}$ ). However, our estimate of absorption efficiency is much higher (65 versus $26 \%$ ) due to lower consumption rates measured in their study ( 0.002 to $0.004 \mathrm{~g}$ kelp $\mathrm{g}^{-1}$ urchin $\mathrm{d}^{-1}$ ). Our estmate is similar to previous measures of absorption efficiency of $S$. droebachiensis feeding on Saccharina longicruris: 49 to $71 \%$ (Miller \& Mann 1973), and 65 to $67 \%$ (Larson et al. 1980). Our study is the first to report absorption efficiencies for $S$. droebachiensis feeding on C. fragile (87\%) and kelp encrusted with Membranipora membranacea (68\%), which are higher than that measured on clean kelp. High estimates of absorption efficiency for each of the 3 algal diets are a combined result of assimilation, loss of dissolved organic matter (DOM) from the food and feces (Field 1972, Miller \& Mann 1973), and microbial degradation of the feces before collection. Loss of DOM due to mechanical damage during feeding may be particularly high for a coenocytic alga such as $C$. fragile. For each diet, the estimate of absorption efficiency also exceeded the organic carbon and nitrogen content. For example, the absorption efficiency for $C$. fragile was $87 \%$, while the combined organic carbon and nitrogen contents of the alga were $18 \%$ (Table 1 , Fig. 3), suggesting loss or assimilation of inorganic matter during feeding.

We used our measures of absorption efficiency for each diet in the laboratory to estimate defecation rates of urchins in the field ( $g$ dry weight feces $\mathrm{g}^{-1}$ urchin $\mathrm{d}^{-1}$ ). Again, we found much higher defecation rates for urchins feeding on clean or encrusted kelp than on Codium fragile. Based on estimated defecation rates in the field, converted to $g$ dry weight feces urchin ${ }^{-1} \mathrm{~d}^{-1}$ using the mass of each individual urchin, and previous measures of average urchin density (143 urchins $\mathrm{m}^{-2}$ ) along a $2.5 \mathrm{~m}$ wide front at Splitnose Point (LauzonGuay \& Scheibling 2007a), we estimated fecal production rates of 74 and $81 \mathrm{~g}$ feces $\mathrm{m}^{-1}$ front $\mathrm{d}^{-1}$ for an urchin grazing front in native (non-encrusted) and invaded (encrusted by Membranipora membranacea) kelp beds, respectively. The estimated fecal production rate of a putative grazing front in a meadow of $C$.

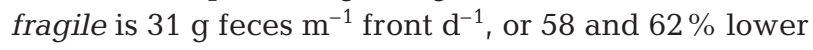
than urchins grazing native and invaded kelp beds, respectively. The estimated production rate of fecal organic carbon, based on carbon absorption efficiency, is higher for urchins grazing native $\left(15.7 \mathrm{~g} \mathrm{C} \mathrm{m}^{-1}\right.$ front $\mathrm{d}^{-1}$ ) than bryozoan-encrusted kelp beds (13.3 $\mathrm{g} \mathrm{C} \mathrm{m}^{-1}$ front $\mathrm{d}^{-1}$ ), and lowest for urchins grazing a C. fragile meadow $\left(4.2 \mathrm{~g} \mathrm{C} \mathrm{m}^{-1}\right.$ front $\left.\mathrm{d}^{-1}\right)$. Due to low nitrogen absorption efficiency on the encrusted kelp diet, estimated fecal nitrogen output was higher for urchins grazing invaded $\left(1.2 \mathrm{~g} \mathrm{~N} \mathrm{~m}^{-1}\right.$ front $\left.\mathrm{d}^{-1}\right)$ than native kelp beds $\left(0.6 \mathrm{~g} \mathrm{~N} \mathrm{~m}^{-1}\right.$ front $\left.\mathrm{d}^{-1}\right)$, and lowest for urchins grazing a C. fragile meadow $\left(0.5 \mathrm{~g} \mathrm{~N} \mathrm{~m}^{-1}\right.$ front $\left.\mathrm{d}^{-1}\right)$.

While these estimates enable general comparisons between native and invaded community states, they are subject to various assumptions and caveats. Notably, our estimates of fecal production rate are based on urchins destructively grazing monospecific stands. When Codium fragile invades an area, there is a transition from kelp bed to Codium meadow during which both algae are interspersed (Scheibling \& Gagnon 2006). Laboratory experiments have shown a 60 to $77 \%$ decrease in consumption rate of $C$. fragile when kelp is present in mixed diets, compared to a single diet of C. fragile (Prince \& LeBlanc 1992, Scheibling \& Anthony 2001, Sumi \& Scheibling 2005). Urchin grazing fronts along the edge of Codium meadows have not been reported in the field, as areas dominated by the invasive green alga in Nova Scotia have not been repopulated by Strongylocentrotus droebachiensis following the urchin mass mortality in the mid- and late 1990s (Scheibling \& Hennigar 1997, Miller \& Nolan 2000). Lyons \& Scheibling (2008) monitored the advance of an urchin front into a mixed algal assemblage at a site $40 \mathrm{~km}$ northeast of Splitnose Point, where $C$. fragile had become established. The urchins consumed only kelp and turf algae, leaving behind patches of $C$. fragile. The low preference for $C$. fragile, and the possibility that urchins may not form dense fronts in or around Codium meadows, suggests that we may have over-estimated fecal production rate for this community state. Although understory turfs (mainly branching and jointed calcareous red algae) are consumed during destructive grazing events, they contribute relatively little to the total fecal production, as turf biomass generally is 2 to 3 orders of magnitude lower than that of kelps or $C$. fragile in established beds (Chapman et al. 2002, Schmidt \& Scheibling 2006). Also, our calculation of fecal production in invaded kelp beds is based on consumption of kelp fronds with $\geq 50 \%$ cover of Membranipora membranacea. Cover of the bryozoan varies both temporally and spatially, and is unlikely to exceed $50 \%$ except during severe outbreaks (Scheibling et al. 1999, Saunders \& Metaxas 2008, Scheibling \& Gagnon 2009).

Our estimates of fecal production may also be biased by measures of absorption efficiency in the fall when it is highest; absorption efficiency of Strongylocentrotus droebachiensis varies up to $30 \%$ seasonally (Miller \& Mann 1973, Larson et al. 1980). Thus, our estimates of 
defecation rate in the field may be conservative on an annual scale. Seasonal variation in algal composition (Lobban \& Harrison 1994) and changes in dietary requirements of urchins with age (Kelly et al. 1998) and season (Larson et al. 1980) also may affect our estimates of fecal output of organic carbon and nitrogen during destructive grazing in each community state. There is no effect of urchin size (juveniles and adults) on absorption efficiency in S. droebachiensis (Miller \& Mann 1973) or feeding frequency in conspecific species (S. purpuratus, Lasker \& Giese 1954, Boolootian \& Lasker 1964; S. intermedius, Fuji 1967), suggesting that fecal production does not vary greatly among individuals in a grazing front, which is composed of mainly large adults (Meidel \& Scheibling 1998).

As a consequence of differences in food quality and urchin absorption efficiency, feces produced on different diets in our study varied in organic content and composition. The ingestion rate of feces is positively linked to the organic carbon and nitrogen content (Frankenberg et al. 1967), and foods with a C:N ratio between 4.5 and 8.5 are generally considered nutritious and readily degraded (Parsons et al. 1984). Pellets of Codium fragile with a $\mathrm{C}: \mathrm{N}$ ratio at the upper limit of this range, and encrusted kelp pellets with a slightly higher C:N ratio, may be important food sources for microbes and suspension and deposit feeders in the subtidal zone (Newell 1965, Johannes \& Satomi 1966, Frankenberg \& Smith 1967). Clean kelp pellets, with a 3- to 4 -fold higher $\mathrm{C}: \mathrm{N}$ ratio, are more likely to be degraded by microbes before being consumed by detritivores. Marine bacterial assemblages have, on average, C:N ratios ranging from 5 to 7 (Fukuda et al. 1998). Therefore, to utilize the organic matter in the kelp feces, bacteria must take up dissolved inorganic nitrogen (nitrate or ammonia) from the surrounding seawater, lowering the $\mathrm{C}: \mathrm{N}$ ratio of the fecal aggregate and increasing its nutritional quality (Wotton \& Malmqvist 2001, Povero et al. 2003). Urchins coat fecal pellets with mucus that adds to their organic content (Lawrence \& Klinger 2001). Codium fragile contains a grazing deterrent (dimethylsulfoniopropionate, Lyons et al. 2007) that may trigger increased mucus production (Lawrence 1975), contributing to the relatively high organic carbon and nitrogen content of fecal pellets. Thus, the lower fecal production rate of urchins feeding on C. fragile may be partly offset by the higher nutritional quality of the feces, compared to feces produced by feeding on kelp.

\section{Dispersal of feces as a food source}

The spatial distribution of feces can substantially affect the structure of benthic assemblages that utilize this food source (Pearson \& Rosenberg 1987, Rosenberg 1995). The extent to which feces are advected along the bottom as bedload, or in the water column as suspended load, depends on their physical characteristics. Settling velocity and critical shear velocity of fecal pellets depend on their density, size, shape, and smoothness (Dietrich 1982, Wiberg \& Smith 1987). Fecal pellets produced on each experimental diet were of similar shape and size. Therefore, differences among settling and critical shear velocities were largely due to differences in density. Pellets of Codium fragile have the lowest density, and therefore the lowest settling and critical shear velocities. Encrusted kelp pellets have a much higher density, likely due to the $\mathrm{CaCO}_{3}$ skeleton and chitinous cuticle of Membranipora membranacea, resulting in higher settling and critical shear velocities. The ratio of settling velocity $\left(w_{s}\right)$ to critical shear velocity $\left(u_{*}\right.$ crit), or Rouse number, determines the likelihood of pellets initially travelling as bedload $\left(W_{s} / \kappa u_{*}\right.$ crit $\left.>1\right)$ or as suspended load $\left(w_{s} / \kappa u_{*}\right.$ crit $<1$; Smith 1977). Patterns in settling and critical shear velocities are similar among the 3 types of fecal pellets, resulting in Rouse numbers well above 1 (C. fragile: 3.2; clean kelp: 5.7; encrusted kelp: 5.7). Thus, urchin feces are most likely to initially travel along the bottom as bedload where they are readily available for consumption by benthic suspension feeders (Nowell et al. 1981, Rosenberg 1995). Once deposited, these feces become a potential food source for deposit feeders (Rosenberg 1995).

To estimate the depth $(h, \mathrm{~m})$ at which each of the 3 fecal pellet types may be deposited throughout the year, we calculated the wave shear velocity $\left(u_{*}\right.$, $\mathrm{cm}$ $\mathrm{s}^{-1}$ ) across depth and compared this to the critical shear velocity $\left(u_{*}\right.$ crit $)$ of each fecal pellet type. We calculated the bottom wave orbital velocity $\left(u_{b_{1}} \mathrm{~cm} \mathrm{~s}^{-1}\right)$ as:

and

$$
u_{b}=(\pi \mathrm{SWH}) / T \sin h(2 \pi h / L)
$$

$$
L=\left(g T^{2}\right) / 2
$$

where $L$ is the wavelength (m), SWH is the significant wave height $(\mathrm{m}$, mean of the largest $1 / 3$ of waves measured), $T$ is the peak wave period (s, highest peak in the 1-dimensional frequency spectrum of waves measured), and $g$ is the acceleration due gravity (9.81 $\mathrm{m} \mathrm{s}^{-2}$ ). Mean monthly SWH and $T$ from 2000 to 2008 were calculated from wave data obtained from a meteorological buoy at the mouth of Halifax Harbour (ID no. C44258, $\left.44^{\circ} 30^{\prime} \mathrm{N}, 63^{\circ} 24^{\prime} \mathrm{W}\right) 11.9 \mathrm{~km}$ to the northwest of Splitnose Point (www.meds-sdmm.dfo-mpo.gc.ca). The mean daily SWH at the Halifax Harbour buoy is highly correlated with the mean daily SWH at Splitnose Point $(r=0.76, p<0.001$ as reported by LauzonGuay \& Scheibling 2007b). We then related the bottom wave orbital velocity to the wave shear velocity using 




Fig. 6. Strongylocentrotus droebachiensis. Depth at which fecal pellets - produced by urchins feeding on Codium fragile, Saccharina longicruris, and $S$. longicruris encrusted with Membranipora membranacea - are deposited during each month of the year. Data were generated using a linear wave model and the critical shear velocity of each fecal pellet type

the equations of Wheatcroft et al. (2007) using a physical roughness $\left(\kappa_{s}\right)$ of $63 \mu \mathrm{m}$, typical of fine silt, and a seawater density $\left(\rho, \mathrm{kg} \mathrm{m}^{-3}\right)$ at a water temperature of $17.0^{\circ} \mathrm{C}$ and salinity of 35 . The resulting depositional depth of urchin feces (i.e. the depth at which wave shear velocity was less than the critical shear velocity of the fecal pellets) varied with both season and diet (Fig. 6). Due to their low critical shear velocity, fecal pellets of $C$. fragile are likely deposited at the deepest depths (33 $\mathrm{m}$ in summer to $55 \mathrm{~m}$ in winter), where they may serve as an important food source due to their low $\mathrm{C}: \mathrm{N}$ ratio and high organic carbon and nitrogen contents. Encrusted kelp pellets, also with a relatively low C:N ratio, are likely deposited at the shallowest depths (22 to $40 \mathrm{~m}$ ) and clean kelp pellets, with a high C:N ratio, at intermediate depths (28 to $47 \mathrm{~m}$ ).

\section{CONCLUSIONS}

The importance of fecal production via grazing of seaweeds by Strongylocentrotus droebachiensis to community structure and biomass, both in the shallow subtidal zone and adjacent deeper habitats, depends on the production rate, quality, and dispersal of the pellets. The rate of total fecal production per unit area $\left(\mathrm{m}^{2}\right)$ by an urchin front (based on our estimates per $\mathrm{m}$ length of a $2.5 \mathrm{~m}$ wide front) in native and bryozoaninvaded kelp beds (30 and $32 \mathrm{~g} \mathrm{~m}^{-2} \mathrm{yr}^{-1}$ respectively), and the output of fecal organic carbon (6.3 and $5.3 \mathrm{~g}$ $\mathrm{m}^{-2} \mathrm{yr}^{-1}$ ) and nitrogen (0.2 and $\left.0.5 \mathrm{~g} \mathrm{~m}^{-2} \mathrm{yr}^{-1}\right)$ by urchin fronts in these community states, is within the range of fecal production rates reported for similar densities (100s to 1000 inds. $\mathrm{m}^{-2}$ ) of suspension feeding bivalves in freshwater (Klerks et al. 1996), estuarine (Jaramillo et al. 1992, Hayakawa et al. 2001), and marine (Zhou et al. 2006) habitats. Fecal production by bivalve assemblages can supply a large proportion of the energy demand of macrobenthic communities, and affect the abundance, biomass, and composition of suspension- and deposit-feeders (Norkko et al. 2001, Norling \& Kautsky 2007, 2008). It is likely that fecal production by $S$. droebachiensis plays a similar role in the subtidal zone. Although empirical data are not yet available to assess this, we know that a vast amount of fecal material is generated during destructive grazing events. Fishery surveys (grazing fronts are targeted by urchin fishers) estimated that $S$. droebachiensis destructively grazed $280 \mathrm{~km}$ along the Atlantic coast of Nova Scotia in the mid- to late 1990s (Miller \& Nolan 2008). This equates to a rate of fecal production of $20720 \mathrm{~kg}$ feces $\mathrm{d}^{-1}$ based on our estimate of fecal production rates for urchin fronts in native kelp beds.

Encrustation of kelp by Membranipora membranacea does not substantially alter the amount of feces produced when urchins feed on kelp, or the total carbon and nitrogen output. However, the feces produced from encrusted kelp have a lower $\mathrm{C}: \mathrm{N}$ ratio and are likely deposited at shallower depths due to their greater density. Urchins grazing on Codium fragile produce less fecal material, carbon, and nitrogen than urchins grazing kelp. However, the feces that are exported have a very low $\mathrm{C}: \mathrm{N}$ ratio, high organic carbon and nitrogen contents, and are likely deposited at the greatest depths. The increase in fecal pellet quality (low $\mathrm{C}: \mathrm{N}$ ratio) and change in depositional depths in the invaded community states (kelp beds with $M$. membranacea, Codium meadows) may alter the energy subsidy to adjacent ecosystems and affect the distribution of macrobenthic assemblages that utilize this resource. The change in quantity of particulate and dissolved organic carbon and nitrogen released into the system, especially in Codium meadows, could also influence local nutrient cycling. Thus, M. membranacea and $C$. fragile not only affect native kelp bed communities, but also may substantially affect energy flow and nutrient cycling within the subtidal ecosystem as a whole.

Acknowledgements. We thank J. Lindley and K. Krumhansl for assistance in the field, T. Wilson and A. Ryan for assistance in the laboratory, and J. Morris and K. Dinning for assistance in calibrating the flume. We thank P. Hill for help with the wave model and P. Hill, J.S. Lauzon-Guay, and D. Lyons for comments on the manuscript. This research was funded by a Discovery Grant from the Natural Sciences and Engineering Research Council of Canada (NSERC) to R.E.S. L.K.S. was supported by a Canada Graduate Scholarship (NSERC). 


\section{LITERATURE CITED}

Bégin C, Scheibling RE (2003) Growth and survival of the invasive green alga Codium fragile ssp. tomentosoides in tide pools on a rocky shore in Nova Scotia. Bot Mar 46: 404-412

Berman J, Harris L, Lambert W, Buttrick M, Dufresne M (1992) Recent invasions of the Gulf of Maine: three contrasting ecological histories. Conserv Biol 6:435-441

Boolootian RA, Lasker R (1964) Digestion of brown algae and distribution of nutrients in purple sea urchin Strongylocentrotus purpuratus. Comp Biochem Physiol 11: 273-289

Breen PA, Mann KH (1976) Destructive grazing of kelp by sea urchins in eastern Canada. J Fish Res Board Can 33: $1278-1283$

Chapman AS, Scheibling RE, Chapman ARO (2002) Species introductions and changes in marine vegetation of Atlantic Canada. In: Claudi R, Nantel P, Muckle-Jeffs E (eds) Alien invaders in Canada's waters, wetlands, and forests. Natural Resources Canada, Canadian Forest Service Science Branch, Ottawa, p 133-148

$>$ Dietrich WE (1982) Settling velocity of natural particles. Water Resour Res 18:1615-1626

Field JG (1972) Some observations on release of dissolved organic carbon by sea urchin Strongylocentrotus droebachiensis. Limnol Oceanogr 17:759-761

Frankenberg D, Smith KL (1967) Coprophagy in marine animals. Limnol Oceanogr 12:443-450

Frankenberg D, Coles SL, Johannes RE (1967) The potential trophic significance of Callianassa major fecal pellets. Limnol Oceanogr 12:113-120

Fuji A (1967) Ecological studies on the growth and food consumption of Japanese common littoral sea urchin Strongylocentrotus intermedius (Agassiz). Mem Fish Fac Hokkaido Univ 15:83-160

Fukuda R, Ogawa H, Nagata T, Koike I (1998) Direct determination of carbon and nitrogen contents of natural bacterial assemblages in marine environments. Appl Environ Microbiol 64:3352-3358

Giles H, Pilditch CA (2004) Effects of diet on sinking rates and erosion thresholds of mussel Perna canaliculus biodeposits. Mar Ecol Prog Ser 282:205-219

Harris LG, Tyrrell MC (2001) Changing community states in the Gulf of Maine: synergism between invaders, overfishing and climate change. Biol Invasions 3:9-21

Hayakawa Y, Kobayashi M, Izawa M (2001) Sedimentation flux from mariculture of oyster (Crassostrea gigas) in Ofunato Estuary, Japan. ICES J Mar Sci 58:435-444

Jaramillo E, Bertran C, Bravo A (1992) Mussel biodeposition in an estuary in southern Chile. Mar Ecol Prog Ser 82:85-94

Johannes RE, Satomi M (1966) Composition and nutritive value of fecal pellets of a marine crustacean. Limnol Oceanogr 11:191-197

Kelly MS, Brodie CC, McKenzie JD (1998) Somatic and gonadal growth of the sea urchin Psammechinus miliaris maintained in polyculture with the Atlantic salmon. J Shellfish Res 17:1557-1562

Kennedy P, Kennedy H, Papadimitriou S (2005) The effect of acidification on the determination of organic carbon, total nitrogen, and their stable isotopic composition in algae and marine sediment. Rapid Commun Mass Spectrom 19: 1063-1068

Klerks PL, Fraleigh PC, Lawniczak JE (1996) Effects of zebra mussels (Dreissena polymorpha) on seston levels and sediment deposition in western Lake Erie. Can J Fish Aquat Sci 53:2284-2291
Knip DM, Scheibling RE (2007) Invertebrate fauna associated with kelp enhances reproductive output of the green sea urchin Strongylocentrotus droebachiensis. J Exp Mar Biol Ecol 351:150-159

Komada T, Anderson MR, Dorfmeier CL (2008) Carbonate removal from coastal sediments for the determination of carbon and its isotopic signature ${ }^{13} \mathrm{C}$ and ${ }^{14} \mathrm{C}$ : comparison of fumigation and direct acidification by hydrochloric acid. Limnol Oceanogr Methods 6:254-262

Lambert WJ, Levin PS, Berman J (1992) Changes in the structure of a New England (USA) kelp bed: the effects of an introduced species. Mar Ecol Prog Ser 88:303-307

> Larson BR, Vadas RL, Keser M (1980) Feeding and nutritional ecology of the sea urchin Strongylocentrotus droebachiensis in Maine, USA. Mar Biol 59:49-62

$>$ Lasker R, Giese AC (1954) Nutrition of the sea urchin, Strongylocentrotus purpuratus. Biol Bull (Woods Hole) 106:328-340

- Lauzon-Guay JS, Scheibling RE (2007a) Behaviour of sea urchin Strongylocentrotus droebachiensis grazing fronts: food-mediated aggregation and density-dependent facilitation. Mar Ecol Prog Ser 329:191-204

> Lauzon-Guay JS, Scheibling RE (2007b) Seasonal variation in movement, aggregation and destructive grazing of the green sea urchin (Strongylocentrotus droebachiensis) in relation to wave action and sea temperature. Mar Biol 151:2109-2118

Lawrence JM (1975) On the relationships between marine plants and sea urchins. Oceanogr Mar Biol Annu Rev 13:213-286

Lawrence JM, Klinger TS (2001) Digestion in sea urchins. In: Lawrence JM (ed) Edible sea urchins: biology and ecology. Elsevier Science, Amsterdam, p 103-113

Levin PS, Coyer JA, Petrik R, Good TP (2002) Communitywide effects of nonindigenous species on temperate rocky reefs. Ecology 83:3182-3193

Lobban CS, Harrison PJ (1994) Seaweed ecology and physiology. Cambridge University Press, Cambridge

Lyons DA, Scheibling RE (2007a) Differences in somatic and gonadic growth of sea urchins (Strongylocentrotus droebachiensis) fed kelp (Laminaria longicruris) or the invasive alga Codium fragile ssp. tomentosoides are related to energy acquisition. Mar Biol 152:285-295

Lyons DA, Scheibling RE (2007b) Effect of dietary history and algal traits on feeding rate and food preference in the green sea urchin Strongylocentrotus droebachiensis. J Exp Mar Biol Ecol 349:194-204

> Lyons DA, Scheibling RE (2008) Context-dependent survival of the invasive seaweed Codium fragile ssp. tomentosoides in kelp bed and urchin barren habitats off Nova Scotia. Aquat Biol 2:17-27

> Lyons DA, Van Alstyne KL, Scheibling RE (2007) Anti-grazing activity and seasonal variation of dimethylsulfoniopropionate-associated compounds in the invasive alga Codium fragile ssp. tomentosoides. Mar Biol 153: $179-188$

> Mamelona J, Pelletier E (2005) Green urchin as a significant source of fecal particulate organic matter within nearshore benthic ecosystems. J Exp Mar Biol Ecol 314:163-174

Meidel SK, Scheibling RE (1998) Size and age structure of the sea urchin Strongylocentrotus droebachiensis in different habitats. In: Mooi R, Telford M (eds) Echinoderms: San Francisco. A.A. Balkema, Rotterdam, p 737-742

Miller RJ (1985) Succession in sea urchin and seaweed abundance in Nova Scotia, Canada. Mar Biol 84:275-286

> Miller RJ, Mann KH (1973) Ecological energetics of the seaweed zone in a marine bay on the Atlantic coast of 
Canada. 3. Energy transformations by sea urchins. Mar Biol 18:99-114

Miller RJ, Nolan SC (2000) Management of the Nova Scotia sea urchin fishery: a nearly successful habitat based management regime. Fisheries and Oceans Science, Canadian Stock Assessment Secretariat, Ottawa

Miller RJ, Nolan SC (2008) Management methods for a sea urchin dive fishery with individual fishing zones. J Shellfish Res 27:929-938

Miller DC, Norkko A, Pilditch CA (2002) Influence of diet on dispersal of horse mussel Atrina zelandica biodeposits. Mar Ecol Prog Ser 242:153-167

Minor MA, Scheibling RE (1997) Effects of food ration and feeding regime on growth and reproduction of the sea urchin Strongylocentrotus droebachiensis. Mar Biol 129:159-167

Nestler EC, Harris LG (1994) The importance of omnivory in Strongylocentrotus droebachiensis (Müller) in the Gulf of Maine. In: David B, Guille A, Féral JP, Roux M (eds) Echinoderms through time. A.A. Balkema, Rotterdam, p 813-818

Newell R (1965) The role of detritus in the nutrition of two marine deposit feeders, the prosobranch Hydrobia ulvae and the bivalve Macoma balthica. Proc Zool Soc Lond 144:25-45

Norkko A, Hewitt JE, Thrush SF, Funnell GA (2001) Benthicpelagic coupling and suspension-feeding bivalves: linking site-specific sediment flux and biodeposition to benthic community structure. Limnol Oceanogr 46:2067-2072

Norling P, Kautsky N (2007) Structural and functional effects of Mytilus edulis on diversity of associated species and ecosystem functioning. Mar Ecol Prog Ser 351:163-175

Norling P, Kautsky N (2008) Patches of the mussel Mytilus sp. are islands of high biodiversity in subtidal sediment habitats in the Baltic Sea. Aquat Biol 4:75-87

Nowell ARM, Jumars PA, Eckman JE (1981) Effects of biological activity on the entrainment of marine sediments. Mar Geol 42:133-153

Parsons TR, Takahashi M, Hargrave B (1984) Biological oceanographic processes, 2nd edn. Pergamon Press, Oxford

Pearson TH, Rosenberg R (1987) Feast and famine: structuring factors in marine benthic communities In: Gee JHR, Giller PS (eds) Organization of communities, past and present. Blackwell Scientific Publishing, Oxford, p 373-395

Povero P, Misic C, Ossola C, Castellano M, Fabiano M (2003) The trophic role and ecological implications of oval faecal pellets in Terra Nova Bay (Ross Sea). Polar Biol 26: 302-310

Prince JS, LeBlanc WG (1992) Comparative feeding preference of Strongylocentrotus droebachiensis (Echinoidea) for the invasive seaweed Codium fragile ssp. tomentosoides (Chlorophyceae) and four other seaweeds. Mar Biol 113:159-163

Provan J, Booth D, Todd NP, Beatty GE, Maggs CA (2008) Tracking biological invasions in space and time: elucidating the invasive history of the green alga Codium fragile using old DNA. Divers Distrib 14:343-354

Rosenberg R (1995) Benthic marine fauna structured by hydrodynamic processes and food availability. Neth J Sea Res 34:303-317

Sauchyn LK, Scheibling RE (2009) Degradation of sea urchin feces in a rocky subtidal ecosystem: implications for nutrient cycling and energy flow. Aquat Biol 6:99-108

Saunders M, Metaxas A (2008) High recruitment of the introduced bryozoan Membranipora membranacea is associated with kelp bed defoliation in Nova Scotia, Canada. Mar Ecol Prog Ser 369:139-151
Scheibling R (1986) Increased macroalgal abundance following mass mortalities of sea urchins (Strongylocentrotus droebachiensis) along the Atlantic coast of Nova Scotia. Oecologia 68:186-198

Scheibling RE, Anthony SX (2001) Feeding, growth and reproduction of sea urchins (Strongylocentrotus droebachiensis) on single and mixed diets of kelp (Laminaria spp.) and the invasive alga Codium fragile ssp. tomentosoides. Mar Biol 139:139-146

Scheibling RE, Gagnon P (2006) Competitive interactions between the invasive green alga Codium fragile ssp. tomentosoides and native canopy-forming seaweeds in Nova Scotia (Canada). Mar Ecol Prog Ser 325:1-14

Scheibling RE, Gagnon P (2009) Temperature-mediated outbreak dynamics of the invasive bryozoan Membranipora membranacea in Nova Scotian kelp beds. Mar Ecol Prog Ser 390:1-13

Scheibling RE, Hatcher BG (2007) The ecology of Strongylocentrotus droebachiensis. In: Lawrence JM (ed) Edible sea urchins: biology and ecology. Elsevier Science, Amsterdam, p 353-392

Scheibling RE, Hennigar AW (1997) Recurrent outbreaks of disease in sea urchins Strongylocentrotus droebachiensis in Nova Scotia: evidence of a link with large-scale meteorologic and oceanographic events. Mar Ecol Prog Ser 152:155-165

Scheibling RE, Hennigar AW, Balch T (1999) Destructive grazing, epiphytism, and disease: the dynamics of sea urchin-kelp interactions in Nova Scotia. Can J Fish Aquat Sci 56:2300-2314

Schmidt AL, Scheibling RE (2005) Population dynamics of an invasive green alga, Codium fragile ssp. tomentosoides, in tidepools on a rocky shore in Nova Scotia, Canada. Ecoscience 12:403-411

Schmidt AL, Scheibling RE (2006) A comparison of epifauna and epiphytes on native kelps (Laminaria spp.) and the invasive green alga (Codium fragile ssp. tomentosoides) in Nova Scotia, Canada. Bot Mar 49:315-330

Schwaninger HR (2008) Global mitochondrial DNA phylogeography and biogeographic history of the antitropically and longitudinally disjunct marine bryozoan Membranipora membranacea L. (Cheilostomata): another cryptic marine sibling species complex? Mol Phylogenet Evol 49:893-908

Smith JD (1977) Modeling of sediment transport on continental shelves In: Golberg ED, McCave IN, O'Brien JJ, Steele JM (eds) The sea, Vol 6. Wiley, New York, p 539-577

Soulsby R (1997) Dynamics of marine sand. Thomas Telford, London

Sumi CBT, Scheibling RE (2005) Role of grazing by sea urchins Strongylocentrotus droebachiensis in regulating the invasive alga Codium fragile ssp. tomentosoides in Nova Scotia. Mar Ecol Prog Ser 292:203-212

Taghon GL, Nowell ARM, Jumars PA (1984) Transport and breakdown of fecal pellets: biological and sedimentological consequences. Limnol Oceanogr 29:64-72

Theriault C, Scheibling R, Hatcher B, Jones W (2006) Mapping the distribution of an invasive marine alga (Codium fragile spp. tomentosoides) in optically shallow coastal waters using the compact airborne spectrographic imager (CASI). Can J Rem Sens 32:315-329

> Turner JT (2002) Zooplankton fecal pellets, marine snow and sinking phytoplankton blooms. Aquat Microb Ecol 27: 57-102

Wheatcroft RA, Wiberg PL, Alexander CR, Bently SJ, Drake DE, Harris CK, Ogston AS (2007) Post-depositional alter- 
ation and preservation of sedimentary strata In: Nittrouer CA, Austin JA, Field ME, Kravitz JH, Syvitski JPM, Wiberg PL (eds) Continental margin sedimentation: from sediment transport to sequence stratigraphy. IAS Spec Publ 37, Blackwell Publishing, Oxford

Wiberg PL, Smith JD (1987) Calculations of the critical shear stress for motion of uniform and heterogeneous sediments. Water Resour Res 23:1471-1480

Editorial responsibility: John Lawrence, Tampa, Florida, USA
Wotton RS, Malmqvist B (2001) Feces in aquatic ecosystems. Bioscience 51:537-544

Zar JH (1999) Biostatistical analysis, 4th edn. Prentice Hall, Englewood Cliffs, NJ

Zhou Y, Yang H, Zhang T, Liu S and others (2006) Influence of filtering and biodeposition by the cultured scallop Chlamys farreri on benthic-pelagic coupling in a eutrophic bay in China. Mar Ecol Prog Ser 317:127-141

Submitted: May 20, 2009; Accepted: September 6, 2009 Proofs received from author(s): November 18, 2009 